This item was submitted to Loughborough's Research Repository by the author.

Items in Figshare are protected by copyright, with all rights reserved, unless otherwise indicated.

\title{
Narratives of peripheralisation: place, agency and generational cohorts in post-industrial Estonia
}

PLEASE CITE THE PUBLISHED VERSION

https://doi.org/10.1177/0969776417711215

PUBLISHER

Sage $($ ) The Authors

VERSION

AM (Accepted Manuscript)

\section{PUBLISHER STATEMENT}

This work is made available according to the conditions of the Creative Commons Attribution-NonCommercialNoDerivatives 4.0 International (CC BY-NC-ND 4.0) licence. Full details of this licence are available at: https://creativecommons.org/licenses/by-nc-nd/4.0/

\section{LICENCE}

CC BY-NC-ND 4.0

\section{REPOSITORY RECORD}

Pfoser, Alena. 2019. "Narratives of Peripheralisation: Place, Agency and Generational Cohorts in Postindustrial Estonia". figshare. https://hdl.handle.net/2134/24898. 
Article accepted for publication in European Urban and Regional Studies

Narratives of peripheralisation: place, agency and generational cohorts in post-industrial Estonia

Alena Pfoser, Department of Social Sciences, Loughborough University, UK

\begin{abstract}
Research on spatial polarisation in Central and Eastern Europe has tended to focus on macro-economic processes that create certain places and people as peripheral and has highlighted the socioeconomic impact of peripheralisation, while paying only limited attention to local experiences and responses. Drawing on a multiscalar conception of peripheralisation processes, the article examines the making of socio-spatial inequalities from the perspective of the periphery and foregrounds the narrative practices through which actors negotiate peripheralisation processes focusing on the case of Narva, a former industrial city in Estonia's Northeastern region. In the face of negative structural dynamics actors rework their peripheral status by articulating a positive sense of belonging, claiming recognition based on their work and trying to exert control over their futures. The paper particularly highlights generational differences within these narrative responses to spatial inequalities. While older workingclass populations' narratives are shaped by collective and place-based resilience, the post-socialist generation employs more individualised strategies in the face of peripheralisation and exercises agency by detaching themselves from place. Analysing these responses, the article draws attention to constrained agency as well as cultural differentiation within peripheral communities.
\end{abstract}

\title{
Keywords
}

Peripheralisation, industrial decline, local strategies, agency, generations, Estonia 


\section{Introduction}

In the past two and a half decades, Central and Eastern Europe has experienced increasing spatial disparities and inequalities. While capital cities could significantly improve their economic performance and living standards, hopes for 'convergence' with the West haven't been fulfilled (Smith and Timar, 2010: 118). Moreover, most states in the region have experienced increasing regional polarisation between metropolitan areas, attracting power, capital and populations, and old industrial, rural and border regions which have been left behind (Smith and Timar, 2010; Gorzelak and Smetkowski, 2010; Ther, 2014; see also the discussion on shrinking cities, Steinführer and Haase, 2007; Martinez-Ferdandez et al, 2012). The introduction of a new round of austerity politics, together with the promotion of competitiveness and the focus on (capital) cities as drivers of regional development have further reinforced these disparities, creating fears over territorial cohesion in the European Union (Hadjimichalis, 2011; PoSCoPP, 2015). Although the focus of much scholarship on regional development in the region still lies on cases of successful transition, an increasing number of scholars have started to draw attention to the processes of regional polarisation and peripheralisation, problematising assumptions of a successful catching up with the West and highlighting the consequences of the recent economic and financial crises in the region. The focus of the analysis lies usually on the macro-economic processes that produce places and their inhabitants as peripheral, their relation to sociodemographic change in the region as well as their economic and social impacts measured by statistical indicators like the dispersion of regional GDP, unemployment figures and population loss (Pickles and Smith, 1998; Gorzelak and Smetkowski 2010; Ferry and McMaster, 2013; Steinführer and Haase, 2007). Scholars have also drawn attention to knowledge production and discursive context in which peripherality and 'difference’ are produced through institutional practices and hegemonic perceptions of space (Kuus, 2013; Lang, 2013). In comparison to these macroapproaches, there is relatively little work on how people living in peripheral areas experience and actively deal with the negative consequences of economic and political restructuring in their everyday lives. While the rich literature on post-socialist survival strategies and economic practices have demonstrated creativity and resilience of people in the region in getting by and sustaining themselves in the face of negative sociospatial developments (Buraway et al, 2000; Rainnie et al, 2002; Round et 
al, 2008; Round and Williams 2010; Stenning et al, 2010; Nagy et al, 2015), this literature often not taken into consideration in conceptualisations of spatial polarisation, which see the "loss of agency of social actors and institutions” (Beetz, 2008: 11; cf. Blowers and Leroy, 1998; Barlösius and Neu, 2008) as a defining feature of peripheralisation processes. Peripheral places and populations largely appear as victims of external forces impacting on them, and in the face of powerful institutional actors and discourses, their practices of dealing with spatial inequalities and marginalisation are considered to be insignificant. As Kühn states in his recent review article "depending on the definition of periphery, the affected actors are considered as disadvantaged, powerless and lacking innovation capacity. Given this, it remains quite unclear what the actual potentials and limits of endogenous strategies to cope with peripheralization are” (Kühn, 2015:11). Furthermore, as a result of the limited engagement with local experiences and responses there is little acknowledgement of the uneven effects peripheralisation has on populations within peripheries and the unequal distribution of resources and agentic capabilities along the axes of class, ethnicity, gender and generation among populations (Vaiou, 2014; Nagy et al, 2015).

Drawing on scholarship on spatial polarisation and post-socialist transformation, this article uses a multiscalar approach to peripheralisation to examine local perspectives on sociospatial change in context. It combines a narrative approach that emphasises how actors interpret and act upon peripheralisation processes in place-based narratives with a macro-perspective that captures the political economy of peripheralisation in the post-Soviet region. In doing so, the article seeks to "keep hold of questions of the social and economic welfare of individuals, households and communities" (Dawley et al, 2008: 283) as articulated by peripheral actors in the context of growing spatial inequalities and also to work against assumptions of populations as unified and passive 'other' that are implicitly or explicitly perpetuated in public discourses on Central and Eastern Europe (Kay et al, 2012; Kuus, 2013).

Empirically, the paper uses Narva, a former industrial town in Estonia's Northeastern region, Ida Virumaa, bordering Russia as a case study. Narva has been heavily industrialised since the $19^{\text {th }}$ century. During the Soviet period, workers from Russia, Ukraine and other Soviet republics were encouraged to move to the region as part of the post-war reconstruction and industrialisation 
programme, turning the region into a largely Russian-speaking working class environment. The economic and political restructuring which followed the restoration of Estonian independence from Soviet rule turned this former centre of Soviet industrial production to a national periphery of questionable reputation associated with social problems and, at least potentially, separatist sentiments.

Through an analysis of place-based narratives, the paper draws attention to the narrative practices of negotiation and resistance in relation to the economic and political peripheralisation processes. In the face of negative structural dynamics, actors rework their peripheral status by claiming recognition, articulating dissent and trying to exert control over their futures. The paper highlights generational differences within these cultural responses to spatial inequalities. While older working-class populations' narratives are shaped by collective and place-based resilience and defiance, younger people employ more individualised strategies in the face of peripheralisation and exercise agency by detaching themselves from place. I argue that these generationally structured forms of dealing with peripheralisation reflect not only age differences but also different cultural resources these agents have at their disposal and indicate a shift towards an internalisation of neoliberal rationalities within the post-socialist generational cohort. Focusing on these generational responses to peripheralisation, the paper sheds light on constrained agency as well as cultural differentiation and change within peripheral communities.

The paper will proceed as follows: after a discussion of the concept of peripheralisation, the paper provides some context on the economic and political processes that have contributed to turning Estonia's Northeastern region into a national periphery. Subsequently, it examines the narratives practices of local working-class populations and their children in dealing with these changes and discusses their implications for spatial development.

\section{Conceptualising peripheralisation: towards a multiscalar approach}

Work on spatial polarisation and peripheralisation is a heterogeneous and growing body of scholarship which shares the conviction that polarisation and peripheralisation need to be studied as "processes that intersect with other aspects of inequality, uneven development and power, and that breach 
conventional territorial boundaries" (PoSCoPP, 2015: 4). Marking a break from conventional depictions of peripheries as clearly determined, structural entities (places and populations "on the periphery”), peripheralisation research shifts the focus from particular sociospatial phenomena to the processes that lead to the emergence and reproduction of peripheries (Barlösius and Neu 2008; Fischer-Tahir and Naumann, 2013; PoSCoPP, 2015; Kühn, 2015). As a consequence, unequal power relations and unequal access to material and symbolic goods which turn places into economically dependent, politically marginal and discursively stigmatised places, become the centre of the analysis. (Neo-)Marxist scholarship on spatial disparities has highlighted how the intrinsic logic of uneven capitalist development acts as the key driver of imbalanced relations and economic dependencies between economic cores and peripheries (Peet and Hartwick, 2009; Nagy et al, 2015). Recent work on spatial disparities replaced some of the economistic and functionalist understandings in this body of scholarship with a relational and multiscalar conception of peripheralisation that, influenced by the cultural turn, emphasises diverse cultural meanings and experiences that contribute to the making of spatial inequalities. Core and peripheral regions are formed relationally and dynamically at intersecting and overlapping spatial scales with different actors and relationships contributing to the production of spatial disparities and inequalities (PoSCoPP, 2015: 1-2; cf. Paasi, 1995; Fischer-Tahir and Naumann, 2013). Anssi Paasi’s work, for example, highlights the complex processes through which regions (including peripheries) are shaped and negotiated within social networks of power (Paasi, 1995; 2010) emphasising in particular what he calls the "fragmented complexity of agency" within region-building (Paasi, 2010: 2300), including those of actors within peripheral areas who negotiate the meaning of and their own position within the centre-periphery relation (Paasi, 1995; Paasi, 2010: 2229). Meyer and Miggelbrink (2013) argue in this context for the need for a subjectcentred approach to better understand peripheralisation processes. Against the established understanding of peripheral actors as economically dependent, powerless and thus insignificant (Blowers and Leroy, 1994; Barlösius and Neu, 2008) this approach recovers the responses and agency of peripheral populations in relation to peripheralisation processes and has the potential to shed light on the micro-dynamics and tactics of getting by, "domesticating” and resisting peripheralisation processes that have been the focus of research on post-socialist post-industrial and rural places 
particularly in the first decade of transition (Buraway et al, 2000; Rainnie et al, 2002; for more recent studies see Round et al, 2008; Round and Williams 2010; Stenning et al, 2010; 2011; Nagy et al, 2015). The article focuses on narratives of peripheralisation as ways of constructing, challenging and reproducing peripheralisation at a local level. Through narrative accounts actors organise experiences of sociospatial change in a thematic and temporal order and by doing so put forward particular visions of present and future. From the perspective of narrative, peripheralisation processes are "narratively promiscuous" (Steinmetz, 1992: 491) as they are based on the processing of experiences and their selection, connection and arrangement into a plot (Somers, 1994). Narratives of peripheralisation can be read as responses to peripheralisation processes in the sense that they offer particular interpretations of self and place in their wider social contexts. These narratives are not purely representational acts but are performative in that they enact particular versions of self and social reality and, drawing on previous experiences and cultural values, guide action and suggest perspectives on the future (Somers, 1994; Chase, 2005). As Mah argues, stories and imaginations of local people are "crucial for shaping urban development perspectives” (Mah, 2012: 193) and thus "have significant implications for how we might tackle issues of industrial ruination and post-industrial transformation” (Mah, 2012: 202). Her Russian case study on the mono-industrial city of Ivanovo shows how narratives of resignation and indifference work as a self-fulfilling prophecy; at the same time positive imaginings of place also provide clues about its future assets - creativity, pragmatism and place attachment of people adapting to processes of change. Researchers working on post-socialist and post-industrial spaces have been calling for some time for a closer examination of these everyday experiences and responses to decline and marginalisation (Stenning and Hörschelmann 2008; Kay et al, 2012; Morris, 2015) and have examined the diversity of strategies adopted to negotiate sociospatial change, both literally in the form of economic formal and informal practices and in terms of constructions of identity and place (Nagy et al, 2016; Hörschelmann and Stenning, 2008). Existing research has identified experiences of loss but also of continuing solidarity, belonging and comfort as examples of everyday resilience (Bonfiglioli, 2014; Morris, 2015) and have also noted more vocal attempts to turn a peripherality into a political resource: in their case study on workers in the Israeli periphery, Cohen and Aharon-Gutman (2014) show how "the broadcasted disempowerment of the periphery" could be turn into a "weapon of the 
weak" using its peripheral location and lack of alternative local livelihoods as a resource for the mobilisation of citizenship claims (Cohen and Aharon-Gutman, 2014: 598). Through these accounts peripheralisation not only appears to have distinctive spatial consequences but is interpreted and acted upon in interpretations of place and place identities. The article adds to these works by offering an indepth exploration of peripheralisation narratives, their forms and effects: How do actors, drawing on personal and collective experiences, narrate sociospatial change, and what consequences do these narratives of peripheralisation have? Do narratives of peripheralisation allow actors to exert agency, and if yes in what ways? What visions of the present and future are presented in them? The empirical analysis, based on a case study in post-industrial Estonia, particularly captures the heterogeneity of narratives of peripheralisation through a comparative analysis of generational cohorts, based on "common location in the social and historical process" (Mannheim, 1998: 168). Comparing two generations of Russian-speakers, the socialist and post-socialist generations, in Estonia's Northeastern region it sheds light on cultural differentiation within peripheral communities. Constituted by working-class populations born between 1920 and mid-1950s, the socialist generation was socialised under the Soviet regime and shared experiences of post-war reconstruction and industrial developments as well as a belief in the Soviet system. The majority of participants had moved to Narva from Russia and other Soviet Republics, had worked as skilled and unskilled workers in industrial production and were often forced into early retirement in the context of the privatisation of the industries. The post-socialist generation (born between 1980 and 1992) in contrast were students studying at the local college or worked in public services or low-skilled temporary jobs.

The analysis of their generational narratives follows a sociological approach to narrative analysis, which situates the processes of ordering and shaping of past experiences within particular social and historical contexts (Maynes, Pierce and Laslett, 2008; Andrews, 2007). It includes an analysis of how understandings of place are embedded within uneven local and regional developments. In a recent contribution, Timar and Velky have argued against the "depoliticising and dematerialisig effect” of the cultural turn in regional geography (Timar and Velkey, 2016: 321; cf. Plüschke-Altof 2016) and called for a renewed focus on the political production of the conditions within which interpretations are situated. Using a multi-scalar approach to peripheralisation, the paper 
responds to this call. It acknowledges both the creative responses and (albeit constrained) agency of peripheral populations as they shape their place but also inequalities and power relations in which they are situated.

The data was collected during several months of ethnographic fieldwork in the northern border region between Estonia and Russia, mostly during a continuous research stay between September 2011 and January 2012. For the purpose of the article I focus on generational differences among the Russian-speaking population in Estonian Narva, encompassing 18 interviews with the socialist generation and 7 interviews with the post-socialist generation, which were collected as part of the larger sample. Participants were approached through personal contacts, voluntary organisations, and educational institutions, aiming to gain a diverse picture of life in the region. The life-story interviews were conducted in Russian language and made use of an open questioning technique, aimed at eliciting stories and creating space for people to structure their accounts (Hollway and Jefferson, 2000; Rosenthal, 1995). They were usually divided into two parts, with a biographical main narration followed by more specific questions about past and present life in the place and lasted between 45 and 210 minutes.

\section{The making of a periphery: Estonia's Northeastern region}

The post-socialist era has been marked by a denigration of workers, manifested not only in the demonisation of working-class communities but also in blaming workers for the woes of society and the vocalisation of 'a desire that society be re-ordered to reward nonmanual labour' (Walkowitz 1995, 163). (...) In stark contrast to the official rhetoric of socialism, more common tropes today... are of the working class as useless, worthless and an obstacle to the 'transition' and of their spaces as grim, grey ghettos (Stenning, 2005: 990).

Once an important centre of industrial production in the Soviet Union's western borderlands, Estonia’s Ida Virumaa (Northeastern) region has been viewed as being “not quite Estonian” in the post-socialist period, a place where "regional problems" - high unemployment, social problems like 
high HIV infection rates and criminality as well as the continuous depopulation - are "most acute" (Kalvet, 2010: 6). During the Soviet period, the region used dominated by oil shale industries, textile manufacturing, construction and chemical industries. Offering relatively high living-standards and a good supply situation, it was an attractive place to live for Russians and people from other Soviet republics who were encouraged to move there as industrial labourers as part of the Soviet industrialisation programme after the destruction of the World War II. Since the 1990s this region has been severely affected by the deindustrialisation and has been politically and economically sidelined. In the city of Narva, Estonia's third largest city and the heart of industrial production in the region, privatisation of factories resulted in large numbers of dismissals; the Krenholm textile factory, which used to employ 12,000 workers, was sold to a foreign investor in 1994 and released the last workers after its bankruptcy in 2010. During the time of my fieldwork, over a quarter of the population was out of work (in comparison to the national average of 16.7\%), and according to the official statistical accounts one third of the population was at risk of poverty (Statistics Estonia, 2015, my calculations; Narva Department for Development and Economy, 2014). Tourism and retail had provided a counter point to the industrial decline and more recently urban development projects supported by the European Union had improved the visual appearance of the city but had not created enough jobs to replace the industrial work. High unemployment and uncertainty also fuelled the outmigration, leading to a shrinking population from 82,200 to 62,100 inhabitants between 1990 and 2014 (Narva Department for Development and Economy, 2014:7).

\section{(Insert figure 1 here)}

Two intersecting developments - post-socialist economic restructuring and nation-building processes - have contributed to the internal peripheralisation of Narva and the Northeastern region within independent Estonia. Rarely examined in conjunction (see however Bohle and Greskovits, 2007, 2012; Kesküla, 2015) these processes have led to a decline of industrial spaces inherited from the Soviet period and economic and symbolic dispossession among its largely Russian-speaking working-class populations.

In their comparative analysis of capitalist transformations in Central and Eastern Europe, Bohle and Greskovits (2007; 2012) label the Baltic States as part of the "neoliberal transformation 
model" where neoliberal prescriptions for the creation of market economies after the fall of the Soviet Union were particularly enthusiastically adopted. The restructuring of Baltic economies was conducted through policies of privatisation and downsizing of industries, liberalisation of foreign trade and investment as well as fiscal austerity. This neoliberal programme was closely tied to the state's reorientation towards Europe, nation-building processes post-1991 (Bohle and Greskovits, 2007: 45), and more recently, found its continuation in an adoption of EU's harshest austerity measures during the financial and economic crises (Sommers and Woolfson, 2014: 6). As Bohle and Greskovits argue:

Radical economic reforms were (...) crucial for the defence of newly acquired national independence, since they were most suitable for cutting the ties with the Russian economy on which these countries depended heavily (Bohle and Greskovits, 2007: 45).

The adoption of these policies has been internationally lauded as a success story, leading to high growth rates and a surging GDP particularly in the years before and after EU accession. However, their polarising effects have been less acknowledged: the industries inherited from the Soviet period were offered limited protection, trade unions were weakened and the minimisation of labour rights and the reduction of social and economic provisions increased the economic pressures. In the peak years of the recession in 2009 and 2010, unemployment and poverty rates soared, creating, as Sommers and Woolson note a "regime of perpetual insecurity and mass impoverishment” (Sommers and Woolfson, 2014: 3), which has particularly affected the working class populations. As Estonia’s working class population consists largely of Russian-speakers who moved from Russia, Ukraine, Belarus and other Soviet republics during the Soviet period and their descendents, the class-related marginalisation intersects with ethnicity (Kesküla, 2015) and was intensified by nationalising policies adopted in the aftermath of the restoration of Estonia's independence. In the early 1990s the Russian-speaking minority made up more than a third of Estonia's total population and was seen as potentially dangerous and destabilising for a small nation of less than a million. A nationalisation agenda was launched, transferring political power to the titular ethnic group and launching citizenship laws that excluded all who moved to Estonia after 1940 as well as their descendents from the national community (Brubaker, 1996). Whereas the exclusive citizenship laws have subsequently been amended and many Russian-speakers did undergo ‘naturalisation' to gain voting rights, the feeling of 
being considered the "internal other" remained - a population viewed as "useless, worthless and an obstacle to the 'transition"” (Stenning, 2005: 990), mirroring discourses that demonise working-class populations in post-industrial areas (Jones, 2011) paired with the specificities of post-Soviet nationbuilding processes.

This othering of Narva's population was reiterated in a seminar on local and regional development, organized by the City Council together with local educational and business organisations, that I attended in October 2011. Despite diverging opinions on the future development and cooperation with Russia, the participants concurred in the concluding discussion that multiple economic and social problems prevented Narva from becoming a 'normal average European town'; the main reason for this lied in the lack of entrepreneurship, the local population was conceived as passive and missing the 'right attitude', laying the responsibility for the development on them (fieldwork notes 7.10.2011). Consequently, the negative depiction of peripheral areas as passive and marginal that has been noted by researchers (Trell et al, 2012; Plüschke-Altolf, 2016) obtained additional ethnic and class dimensions in the case of Narva.

The following two sections discuss how different generational cohorts of Russian-speakers, the socialist and post-socialist generations, living in Narva responded to the peripheralisation of their place in the context of the economic restructuring and nationalisation processes.

\section{Negotiating peripheralisation: industrial decline, discontent and resilience}

Peripheralisation was something that was intensely felt during my fieldwork in the former industrial centre of Narva between 2011 and 2012, a time when the consequences of the financial and economic crisis were particularly visible. Participants regularly spoke about their city as a place in decline; empty factory buildings or derelict houses that could be found in many places in the city were used in narratives as physical markers to underline decline contrasted to the progress and "good life" during the Soviet past as well as present developments in the national capital, where in the words of one participant, a "new and beautiful Tallinn” had been constructed (Interview with Raisa, b.1950, 02.11.2011). In contrast to institutional and media discourses, which framed the "regional problems" 
in Estonia's Northeastern region largely as a self-produced status due to lack of local adaptation and entrepreneurship (Kalvet, 2010), from a local perspective the industrial decline, spatial inequalities and marginalisation were seen as the result of a (planned) destruction by the state and capital.

The dominant narrative pattern in the interviews was the construction of discontinuity (Zerubavel, 2003), in which the centrality of Narva during socialism was followed by a decline and peripheralisation since the break-up of the Soviet Union. Participants belonging to the socialist generation had engaged often for several decades in heavy industrial labour, propagated under socialism as "inherently meaningful and noble" and thus acquired a particular "moral significance" within society (Ashwin, 1999:10). Industrial work had not only secured the livelihood but also been a locus of identification and pride which contributed together with more mundane experiences to a sense of "progress" and "good life under socialism", embedded in teleological narratives of socialism in comparison to which negative effects on health and experiences of scarcity were minimised. The economic and psychological insecurities of immediate transition, the closing of factories, the loss of social security arrangements and the effects of the financial and economic crisis formed different temporal layers that accumulated in a sense of being abandoned and left behind (cf. Laitin 1998, 105157; these narratives mirror experiences of insecurity in other places of the post-Soviet region, cf. Shevchenko 2009). Mariia, a chemist in her late sixties, who worked at the Balti TS factory till her retirement in 2003, particularly highlighted the 1990s as a turning point:

In the beginning they sold the social sphere, the nursery schools, our house of culture named after the $50^{\text {th }}$ anniversary of the October revolution. (At work) we were living under the threat of dismissal. There was this sword of Damocles above us all the time during the disintegration of the factory, because people kept being dismissed from work. (Interview with Mariia, b. 1943, 19.11.2011)

Maksim, an unskilled worker, who had worked as an electrician at the Kreenholm textile manufacturing plant, linked the break-up of the Soviet Union more clearly to shifting power relations and collective difficulties experienced by Russian workers in Estonia: 
I worked in Balti TS for quite a long time and in 1991 I started to work for Krenholm. In August it happened, the Soviet Union broke apart and within half a year we were... most interestingly, even though we were simple, uneducated people, not academics, but we knew that it would be very bad for simple Russian workers (...) the Russians were always thought to be occupants. (Interview with Maksim, b.1947, 05.11.2011)

Following the break-up of the Soviet Union Russian-speaking workers like Mariia and Maksim often experienced extreme financial and psychological insecurity, only partially reflected in the city's official poverty and unemployment statistics. Their monthly pension of 300 Euros did hardly suffice to cover their expenses and had to be combined in the case of Mariia with forms of self-provisioning from her dacha and additional income from seasonal work abroad and in Maksim's case from irregular cross-border trade. Peripheralisation processes and their diverse manifestations were seen by their generation as deliberate attempts of destroying Narva and making its Russian-speaking population leave. However, the narratives of the socialist generation did not only convey a sense of powerlessness in the face of these changes but also showed creative ways of negotiating and reworking their position within Estonia.

Morris' observations the "efforts in making personal worlds habitable" through "small agency that is locally and socially embedded” in Russian industrial towns (Morris, 2015) are useful in this context. Despite the negative developments the socialist generation demonstrated resilience and made Narva their home through practical arrangements like the usage of welfare payments, self-provisioning and informal work, including cross-border trade (Stenning et al, 2010; Bruns and Miggelbrink, 2012), strategies which were not limited to the period of immediate transition but continued to form an important source of income, especially at a time of increased unemployment during the economic crisis. At the same time resilience was articulated in narrative constructions of belonging and being at home. Mariia contrasted her sense of belonging to what she saw as a conscious attempt by the Estonian government to displace:

They want us to feel like foreigners here, this is why they destroy this place (...) but those years [under Soviet rule], you can't throw them away; you can't throw them out of your life, out of history, out of everything. The people who were born here, who have grown up here, this is 
their homeland (rodina), isn't it? (Interview with Mariia, b. 1943, 19.11.2011)

Evgeni, 61-years old, who had worked as an electrician in the textile manufacturing plant Krenholm, and now lived from his pension and additional income from cross-border trade, was more assertive:

This is my home and no matter how the Estonians relate to me and how I relate to them, this is my city (Interview with Evgenii, b. 1944, 08.11.2011).

Anchored in memories, personal relations and pride in the ability to get by, these narratives emphasised their belonging in place. Narratives of belonging can be seen as acts of resilience, constructing a habitable place despite the destruction but also need to be seen as acts of "talking back" to the state and articulating dissent with the developments. This was also apparent in a second narrative strategy employed by the socialist generation, drawing on what Eeva Kesküla has called in her study on Russian-speaking miners in Estonia a "discourse of hard work". This discourse of hard work is a "way of ordering their world and having a voice" in Estonian society (Kesküla, 2015: 103) and is informed by the physically demanding character of industrial work that was often damaging for workers' health as well as the Soviet ideology that considered hard physical work as particularly valuable (Ashwin, 1999). Talking about past and present work, Russian-speaking workers in Narva similarly demanded respect for their contribution to Estonian society. Maksim complained how Estonia had profited from their work and the industries the Russians had reconstructed after the war in the region while paying them miserable pensions. "We were working for them. This is why the Estonians always lived better than the Russian people” (Interview with Maksim, b.1947, 05.11.2011). Showing me around in the extremely loud and dusty oil shale-fuelled power station, another participant emphasised that Estonia relied on their work as they provided the country with energy. Aleksandr continued to hold a position in the power station where his father had worked but had experienced increasing pressures both in terms of workload and pay, as salaries did not keep up with the rising price regime. Aleksandr clearly experienced pride in his work and technical expertise but the lack of recognition and remuneration had started to undermine his sense of purpose (fieldwork diary 9 June 2012). 
These narratives of hard work and belonging constitute small acts through which the socialist generation reworked what it meant to be at the periphery - as a Russian-speaker and a (former) worker in Estonia. Through acts of resilience and contestation Russian-speakers questioned the hardships and their internal othering within Estonia, enacting themselves as citizens instead of passive subjects of peripheralisation (Cohen and Aharon-Gutman, 2014).

\section{Escaping peripheralisation? Mobilities and uncertain futures}

Studies on young people in rural and post-industrial regions have emphasised their ambivalent position as they face greater risks and uncertainties but also have a greater sense of agency and the ability to shape their fate (Wiest, 2015; Nugin, 2008). As Nugin (2008) found in a study on ethnic Estonians young people can interpret uncertainty differently and respond to it with competitiveness and self-responsibilisation (Nugin, 2008: 201), demonstrating the need for a cultural perspective that uncovers the meanings of uneven development and associated uncertainties. Coming of age within a neoliberal market economy, the post-socialist generational cohort in Narva was not only confronted with different tasks like entering the employment market and choosing a profession but also had a different set of cultural references and expectations which influenced their experiences of place and ways of dealing with peripherality. Similarly to the socialist generation, they conceived of Narva as a peripheral place but focused on their present and future perspectives within the city and,, in contrast to the older generation's collective place-based narratives, they disconnected themselves from Narva and envisioned a future elsewhere.

Aleksandr's daughter Irina, a 22-years old student who studied English at the local college, told me in our first encounter that she had "dreamt of moving abroad since (her) childhood". She was an active student, organised film screenings at the local college, volunteered at the radio station and was keen to make use of the Erasmus programme that her educational institution offered:

I know that I will definitely leave this place. Of course they (my parents) understand.

Here I just... even my dad sometimes jokes: 'you are going to work at the power plant 
and continue our cause, right?' [laughs]. They have been working there for all their lives and I should follow them, right? [jokingly]. (Interview with Irina, b.1989, 29.10.2011)

Despite her working-class background, the Soviet models of hard industrial labour, which still dominated in the local employment structure and which the older generation including her father used to claim recognition, were not longer considered to be desirable for her. Imagining migration was a reaction to the lack of regular and well-paid employment but also related to a shift in economic and cultural frameworks that devalued industrial work. Irina emphasised that her decision to study at the local college was taken pragmatically but that it was only temporary, "I always knew that I would leave and I'm waiting for that moment when this possibility emerges, to be precise I was already given the chance to leave next semester, as an exchange student. In any case I don't want to stay in Estonia, this is not my country, the country where I want to live.”

Alongside positive expectations and hopes of leaving, staying put also was connected with the fear of being left behind and having minimal chances. Igor, a social work student in his late twenties, had moved first to Russia where he made a living with petty-trade but returned to Narva to complete his studies. Despite his emotional attachment to Narva - similarly to the older generations he felt he belonged in place due to his family relations and the leisure activities he was involved in, he constructed Narva as transit point. "If I stay here, I need to think what to do in old age if everything closes down and I won't be competitive on the labour market”, stated (Interview with Igor, b.1983, 09.01.12). His colleague Elena, who was preparing to go to Germany to work as a teaching assistant, shared these fears. With both her parents unemployed, she knew that she had to rely on herself to make a living.

You know to stay in Narva, of course, this is my home. But you can sink to the ground. I see many of the girls I know from childhood. There is this girl that used to be young now she has become coarse (obabilas). Heavy bags, she leaves the Maxima shop with bread, sausages, looks to the floor. You know everything about her. She's gone, now there's only dullness (byt, byt, byt). How to earn money, feed your family, watch TV series, you know you can sink to the ground. (Interview with Elena, b.1989, 29.10.11) 
Elena's quotation expresses a connection between the place where one lives and one's personal identity, with Narva's lack of opportunities directly impacting people's mindset and ways of life. Leaving in this regard was tied in with the hope to escape peripherality and not to "sink to the ground", even if it involved great uncertainty:

Nobody is waiting for me to work there. I am not sure who's waiting at all. This is the problem. I have to find out... You have to try.

The narrative dissociation from Narva was linked to an aspirational discourse which expressed hopes and desires for a better and different life elsewhere. However, the translation of geographical mobility into social mobility was highly uncertain. Within Estonia, Russian-speakers had higher unemployment rates and often remained marginalised even if they lived in the capital (Ehala, 2009) and had made efforts to learn Estonian language and gain citizenship status. The employment possibilities in a Europe shaken by the economic crisis seemed equally uncertain. Dissociation from place through imaginations of future mobility was an individualised response that expressed the need and ability to compete and improve one’s chances. Evgeni’s emphasis on “competitiveness” and Elena’s “you have to try” construct mobility as necessary and natural response. They express the belief in the ability to shape one's fate (Wiest, 2015; Nugin 2008) but also constitute a forced strategy due to the perceived lack of alternatives.

As a response to peripheralisation dissociation from place is more than an age-related phenomenon that can be explained by the fact that young people who are seeking to enter the job market are looking for opportunities elsewhere. The generational divide relates to opportunities, skills and education between generations but also to different self-understandings and rationalities, with young people seeking more individualised strategies and even distancing themselves from the life models of their working class parents. The discourses of competitiveness and self-transformation and optimisation reflect new neoliberal rationalities within post-Soviet region (Makovicky, 2014) and entail risk seeking and enterprising activities, which stand in sharp contrast to the place-based collective responses of the socialist generations. Morris (2015: 33) interprets resilience and habitability of Russian-workers as "humble categories of alternative existence" which are directed at avoiding the "self-transformative work" imposed by neoliberalisation by striving to be self-sufficient. 
What is more, in the case of Narva's socialist generations, expressions of dissent actively opposed the negative effects of the transformation and its effects on their place. In comparison to this, the narratives of the post-socialist generations demonstrate a different kind of agency, internalising the responsibility for self-development and striving to maximise their individual opportunities. When I asked Elena about when she thought was the best period for Narva, she stated that

Everything depends on how you look at it. There are different periods, and people perceive them in different ways. Some people are happy that shopping centres are built, that's great. Others have a look at it and say: the city is lost, only magazines are left. We are all looking at it through our own prism. (Interview with Elena, b.1989, 29.10.11)

\section{Conclusion}

The economic and political restructuring in Eastern Europe is often narrated in terms of a success story bringing about integration into a shared political space and market economy, a narrative that is even reproduced in relation to the recent rounds of austerity measures adopted as a reaction to the financial and economic crises. Places and populations at the margins question this success story; they absorb the negative effects of the changes and demonstrate the multiple inequalities and exclusions they produce. If they appear in the national media they are often portrayed as negative others and blamed for lacking the initiative to take responsibility for their own fate, a portrayal that detaches the local situation from the macro processes of spatial polarisation that are an essential part of the transformation. This article aimed to analyse the narrative accounts of local communities as part of a multiscalar approach to peripheralisation. While local populations are embedded within larger economic and political dynamics and their narratives have to be analysed in a context of power inequalities, by mobilising a variety of cultural and social resources they exercised "constrained agency” within peripheralisation processes (Coe and Jurdhus-Lier, 2011 cit in Cohen and Aharon-Gutman, 2014: 594). Narratives of peripheralisation, the diverse ways of constructing, challenging and reproducing peripheralisation, are generationally structured. The narratives of the socialist generation were to some extent rooted in industrial identities of the past and focused on the collective experience of industrial decline and 
ethnic discrimination. By tracing a negative development and positioning themselves as victims, their narratives reproduced their status as a marginalised group and their place as a national periphery. At the same time, they tried to counter negative dynamics through claiming recognition as workers who had contributed to national development and mobilising local pride and belonging. In contrast to these collective and place-based narratives, the narratives of generation who came of age during or after the post-socialist transition were shaped by the neoliberal language of self-optimisation and the desire to improve their life chances through imagined and real mobilities, showing a generational shift away from collective working class identities towards more individualised rationalities dominated by the premise to mould the self to adapt to changes.

Narratives of peripheralisation are not only relevant in that they guide everyday actions and shape local livelihoods but, as part of the making of peripheries, are "crucial for shaping urban development perspectives” (Mah, 2012: 193). Despite their differences, both strategies in different ways perpetuate the peripheral position of Estonia's Northeastern region. The narratives of the former workers are rooted in Soviet discourses and particular identities that have been devalued by the regime to contest the economic and political developments and thus are unlikely to be listened to. The strategies of the post-socialist generation in contrast fit much better the aims of the radical transformation agenda in Estonia that in the words of the former prime minister Mart Laar, aims to “inspir(e) people to assume responsibility for their own future” (Mart Laar 2002, cit in Bohle and Greskovits, 2012: 125). At the same time, however, they do not mitigate spatial polarisation processes; as post-socialist generations, similar to many young people in peripheral locations in Europe, dissociated themselves from place and employing individualised strategies to optimise their own chances, rather than trying to reverse the negative developments in place.

These findings demonstrate the need for a differentiated analysis of peripheral communities that takes into account the diversity of strategies that actors employ to inhabit, negotiate, contest and reproduce peripheralities as well as the need to embed them in a wider political and economic analysis. Although the narrative accounts demonstrate creative agency and the ability to talk back to the centre, they are shaped by economic and social insecurities and "infused with unequal power relations” (Round et al, 2008: 181) that characterise the life of many people at Europe's new 
peripheries. Emphasising local agency in relation to peripheralisation processes thus should not mean to overemphasise or even romanticise the practices of the peripheral communities but to achieve a complex and grounded picture through which territorialised inequalities and exclusions are experienced and dealt with on an everyday level..

\section{Acknowledgements}

The research for this article was conducted within the project "Socio-economic and Political Responses to Regional Polarisation in Central and Eastern Europe” (RegPol$\left.{ }^{2}\right)$, coordinated by the Leibniz Institute for Regional Geography, Leipzig/ Germany. The project received funding from the People Programme (Marie Curie Actions) of the European Union's Seventh Framework Programme FP7/2007-2013/ under REA grant agreement $n^{\circ}$ 607022. The collection of empirical data was supported by Loughborough University’s Graduate School Studentships (October 2010-September 2013). I would like to thank the editor and the two anonymous reviewers for their comments on earlier versions of this paper.

\section{Bibliography}

Andrews M (2007) Shaping history: narratives of political change. Cambridge: Cambridge UP. Ashwin S (1999) Russian Worker: The Anatomy of Patience. Manchester: Manchester University Press.

Barlösius E and Neu C (eds) (2008) Peripherisierung-eine neue Form sozialer Ungleichheit. Berlin: Brandenburgische Akademie der Wissenschaften.

Beetz S (2008) Peripherisierung als räumliche Organisation sozialer Ungleichheit. In: Barlösius E and Neu C (eds) (2008) Peripherisierung-eine neue Form sozialer Ungleichheit. Berlin: Brandenburgische Akademie der Wissenschaften, 7-16.

Blowers A and Leroy P (1994) Power, politics and environmental inequality: a theoretical and empirical analysis of the process of ‘peripheralisation’. Environmental Politics 3(2): 197-228.

Bohle D and Greskovits B (2007) Neoliberalism, embedded neoliberalism and neocorporatism: Towards transnational capitalism in Central-Eastern Europe. West European Politics 30(3): 443-466. 
Bohle D and Greskovits B (2012) Capitalist Diversity on Europe's Periphery. Ithaca: Cornell University Press.

Bonfiglioli C (2014) Gender, labour and precarity in the South East European periphery: the case of textile workers in Stip. Contemporary Southeastern Europe 1(2): 7-23.

Brubaker R (1996) Nationalism Refrained: Nationhood and the National Question in the New Europe. Cambridge: Cambridge UP.

Bruns B and Miggelbrink J (eds) (2012) Subverting borders: doing research on smuggling and smallscale trade. Wiesbaden: Verlag fuer Sozialwissenschaften.

Burawoy M, Krotov P and Lytkina T (2000). Involution and destitution in capitalist Russia. Ethnography 1(1): 43-65.

Chase, Susan E. Narrative inquiry. Multiple Lenses, approaches, voices. In: Denzin, Norman K and Yvonna S. Lincoln. (eds) The Sage Handbook of qualitative research. $3^{\text {rd }}$ edition. London: Sage, 2005; pp.651-679.

Cohen N and Aharon-Gutman M (2014) Citizenship at work in the Israeli periphery: the case of Peri Ha’Galil. Environment and Planning D: Society and Space 32(4): 589-605.

Dawley S, Stenning A and Pike A (2008) Mapping Corporations, Connecting Communities Remaking Steel Geographies in Northern England and Southern Poland. European Urban and Regional Studies 15(3): 265-287.

Ehala M (2009) The Bronze Soldier: identity threat and maintenance in Estonia. Journal of Baltic Studies 40(1): 139-158.

Ferry M and McMaster I (2013) Between growth and cohesion: new directions in Central and East European regional policy. Europe-Asia Studies 65(8): 1499-1501.

Fischer-Tahir A and Naumann M (2013) Introduction: peripheralization as the social production of spatial dependencies and injustice. In: Fischer-Tahir A and Naumann M (eds) Peripheralization: the Making of Spatial Dependencies and Social Injustice. Wiesbaden: Springer VS, 9-26. 
Gorzelak G and Smętkowski M (2010) Regional development dynamics in Central and Eastern European countries. In: Gorzelak G, Bachtler JF, Smetkowski M (eds) Regional Development in Central and Eastern Europe: Development Processes and Policy Challenges. London: Routledge, 3458.

Hadjimichalis C (2011) Uneven geographical development and socio-spatial justice and solidarity: European regions after the 2009 financial crisis. European Urban and Regional Studies 18(3): 254274.

Hollway W and Jefferson T (2000) Doing Qualitative Research Differently: Free Association, Narrative and the Interview Method. London: Sage.

Hörschelmann K and Stenning A (2008) Ethnographies of postsocialist change. Progress in Human Geography 32(3): 339-361.

Jones O (2011). Chavs: the demonization of the working class. London: Verso.

Kay R, Shubin S and Thelen T (2012) Rural realities in post-socialist space. Journal of Rural Studies 28 (2012): 55-62

Kalvet T (2010) Country Report on Achievements of Cohesion Policy: Estonia. Expert Evaluation Network Delivering Policy Analysis on the Performance of Cohesion Policy 2007 - 2013. Brussels: DG Regional Policy.

Kesküla E (2015) Reverse, restore, repeat! Class, ethnicity, and the Russian-speaking miners of Estonia. Focaal 72(2015): 95-108.

Kühn M (2015) Peripheralization: theoretical concepts explaining socio-spatial inequalities. European Planning Studies 23(2): 1-12.

Kuus M (2013) Places of lower rank: margins in conversations. Political Geography 37: 30-32.

Makovicky N (ed) (2014) Neoliberalism, Personhood, and Postsocialism: Enterprising Selves in Changing Economies. Farnham: Ashgate.

Lang T (2013) Conceptualising urban shrinkage in East Germany: understanding regional Polarization 
in the light of discursive forms of region building. In: Fischer-Tahir A and Naumann M (eds) Peripheralization: the Making of Spatial Dependencies and Social Injustice. Wiesbaden: Springer VS, 224-238.

Mah A (2012) Industrial ruination, community, and place: landscapes and legacies of urban decline. Toronto: University of Toronto Press.

Mannheim K (1998 [1952]) The Sociological Problem of Generations. In: Mannheim K Essays on the Sociology of Knowledge. London: Routledge and Kegan Paul, 163-195.

Martinez-Fernandez C, Audirac I, Fol S, and Cunningham-Sabot E (2012) Shrinking cities: Urban challenges of globalization. International Journal of Urban and Regional Research 36(2): 213-225.

Maynes M Jo, Jennifer L P and Laslett B (2008) Telling stories: the use of personal narratives in the social Sciences and history. Ithaca and London: Cornell UP, 2008.

Meyer F and Miggelbrink J (2013) The subject and the periphery: about discourses, on loopings and ascriptions. In: Fischer-Tahir A and Naumann M (eds) Peripheralization: the Making of Spatial Dependencies and Social Injustice. Wiesbaden: Springer VS, 207-223.

Morris J (2015) Notes on the "worthless dowry” of Soviet industrial modernity: making working-class Russia habitable. Laboratorium 7(3): 25-48.

Nagy E, Timar J, Nagy G and Velkey C (2015) The everyday practices of the reproduction of peripherality and marginality in Hungary. In: Lang T, Henn S, Kornelia E, Sgibnev W (eds) Understanding New Geographies of Central and Eastern Europe. Socio-Spatial Polarization and Peripheralization in a Rapidly Changing Region. Basingstoke: Palgrave, 135-154.

Narva Department for Development and Economy. Narva Arvudes/ Narva in Figures. Narva, 2014.

Nugin R (2008) Constructing adulthood in a world of uncertainties: Some cases of post-Communist Estonia. Young 16(2): 185-207. 
Paasi A (1995) The social construction of peripherality: the case of Finland and the Finnish-Russian border area. In: Eskelinen H, Snickars F (eds) Competitive European Peripheries. Berlin: Springer, 235-258.

Paasi A (2010) Regions are social constructs, but who or what 'constructs' them? Agency in question. Environment and Planning A 42(10): 2296-2301.

Peet, R and Hartwick E (2009) Theories of Development: Contentions, Arguments, Alternatives. New York: Guilford Press.

Pickles J and Smith A (eds) (1998) Theorising Transition: the Political Economy of Postcommunist Transformations. London: Routledge.

Plüschke-Altof B (2016) Rural as periphery per se? Unravelling the discursive node. Sociální studia/Social Studies 13(2): 11-28.

PoSCoPP (Research Group Production of Space in the Context of Polarisation and Peripheralisation) (2015) Understanding new geographies of Central and Eastern Europe. In: Lang T, Henn S, Kornelia E, Sgibnev W (eds) Understanding New Geographies of Central and Eastern Europe: Socio-Ppatial Polarization and Peripheralization in a Rapidly Changing Region. Basingstoke: Palgrave, 1-24.

Rainnie A, Smith A, and Swain A (eds) (2002) Work, Employment, and Transition: Restructuring Livelihoods in Post-communism. London and New York: Routledge.

Rosenthal G Erlebte und erzählte Lebensgeschichte. Gestalt und Struktur biographischer Selbstbeschreibungen. Frankfurt a. M.: Campus, 1995.

Round J, Williams C and Rodgers P (2008) Everyday tactics and spaces of power: the role of informal economies in post-Soviet Ukraine. Social \& Cultural Geography 9(2): 171-85.

Round J and Williams C (2010) Coping with the social costs of 'transition': everyday life in postSoviet Russia and Ukraine. European Urban and Regional Studies 17(2): 183-196.

Smith A and Timár J (2010) Uneven transformations: space, economy and society 20 years after the collapse of state socialism. European Urban and Regional Studies 17(2): 115-125. 
Somers M R (1994) The narrative constitution of identity: A relational and network approach. Theory and Society 23(5): 605-649.

Sommers J and Woolfson C (2014) Introduction: the Baltics and the political economy of austerity. In: Sommers J, Woolfson C (eds) The contradictions of austerity: the socio-economic costs of the neoliberal Baltic model. London: Routledge, 1-16.

Statistics Estonia (2015) Statistical database. Available at: https://www.stat.ee/.

Steinführer A and Haase A (2007) Demographic change as a future challenge for cities in East Central Europe. Geografiska Annaler: Series B, Human Geography 89(2): 183-195.

Steinmetz G (1992) Reflections on the role of social narratives in working-class formation: narrative theory in the social sciences. Social Science History 16(3): 489-516.

Stenning A (2005) Where is the post-socialist working class? Working-class lives in the spaces of (post-)socialism. Sociology 39(5): 983-999.

Stenning A and Hörschelmann K. (2008). History, geography and difference in the post- socialist world: or, do we still need post- socialism? Antipode 40(2): 312-335.

Stenning A, Smith A, Rochovská A and Swiatek D (2010) Domesticating neoliberalism: spaces of economic practice and social reproduction in post-socialist cities. Oxford: Wiley-Blackwell.

Ther P (2014) Die neue Ordnung auf dem alten Kontinent: Eine Geschichte des neoliberalen Europa. Frankfurt/M.: Suhrkamp.

Timár J and Velkey G (2016) The relevance of the political economic approach: The interpretations of the rural in the migration decision of young women and men in an economically backward region. Journal of Rural Studies 43(1): 311-322.

Trell E, van Hoven B and Huigen P (2012) 'It's good to live in Järva-Jaani but we can't stay here': Youth and belonging in rural Estonia. Journal of Rural Studies 28(2): 139-148.

Vaiou, D (2014) Tracing aspects of the Greek crisis in Athens: putting women in the picture. European Urban and Regional Studies 00: 1-11 (accessed 26 January 2016). 
Wiest K (2015) Migration and everyday discourses: peripheralisation in rural Saxony-Anhalt from a gender perspective. Journal of Rural Studies 00: 1-11 (accessed 10 December 2015)

Zerubavel E (2003) Time maps: collective memory and the social shape of the past. Chicago: University of Chicago Press. 